\title{
A SET OF SILVER DENTAL INSTRUMENTS FROM THE NEW MILTON COLLECTION
}

\author{
by
}

\author{
G. M. LONGFIELD-JONES*
}

\begin{abstract}
THIS short paper studies a set of ten silver instruments belonging to the New Milton Collection, which are believed to be dental and of Roman date. A brief history of the set is given, also a description of each instrument together with suggested name and function, based upon the accounts of dental procedures recorded in classical medical texts. In an attempt to determine the antiquity of the set, results of non-destructive tests upon two of the instruments are compared with those of metal artefacts of authenticated date. In addition, stylistic comparisons are made with ancient instruments in museum collections, and representations of instruments upon ancient stelae and in medical manuscripts.
\end{abstract}

From November to December 1982 an interesting selection of Greek and Roman antiquities from the New Milton Collection of Mr Richard Hattat was exhibited in the Star Case of the Randolph Gallery at the Ashmolean Museum, Oxford.

Among the numerous items displayed were red and black figure Greek vases, including the Amphora-Name-Vase of the new Hattat Painter, Roman red ware vases, vessels, lamps, brooches, and ten dual-purpose surgical or dental instruments, especially noteworthy in that they were of silver, and from their design and decoration, constituted a set. These instruments, brought from Istanbul about fifteen years ago and believed to be for use in dentistry, had been put up for sale on 15 July 1980, at Sotheby's Park Burnet of New Bond Street, London, where they formed part of Lot 179:1 "A Roman bronze Appliqué in the form of a winged human head, 3 1/8 ins (8 cms); a Group of Roman bronze Surgical and other Implements; a Roman bronze bust of a warrior wearing a crested helmet 5 ins $(12.8 \mathrm{cms})$, c. 1st/2nd Century AD; and a bronze Ram's Head". The present owner acquired them shortly after this date, catalogued them nos. 1559-1568 (see Figure 1), and set aside no. 1566 to be left in the original state at the time of purchase for future reference if necessary. The remaining nine were treated to remove patina/corrosion and became silver in appearance. ${ }^{2}$

The instruments vary in length from $12 \mathrm{cms}$ to $15.7 \mathrm{cms}$ and have olivary nuclei

* Dr G. M. Longfield-Jones, MA, Silver Birches, Poyle Lane, Burnham, Bucks SL1 8LA.

\footnotetext{
${ }^{1}$ I am indebted to the Antiquities Department of Sotheby Parke Burnet \& Co. and Mr Richard Hattat for assistance in discovering the history of the dental instruments.

${ }^{2}$ Not an uncommon occurrence, I believe, where in a base silver, preferential seepage has taken place.
} 
finials incised with encircling lines. The slender round shafts are decorated with an identical pattern - raised rings framing a boss or crude baluster - which occurs twice on each instrument, beneath the head and as a central fingerhold, except on nos. 1567 and 1559, which are somewhat shorter than the rest. It is the combination of matching nuclei, shafts, and decoration which marks the instruments as a "set" and is somewhat reminiscent of the bronze instruments from Herculaneum illustrated in Védrènes' translation of Celsus. ${ }^{3}$ But too much should not be made of this, for rings and baluster patterns are commonly found on Graeco-Roman surgical/toilette implements. These instruments give the impression of having been cast in a mould and then worked upon, because the decorative patterns are not as elegant or regular as in many cast instruments, while the incisions in the nuclei are not absolutely uniform. This may be the result of casting in an inferior mould, as it is clear from artefacts extant in many museum collections that Roman smiths were very well able to cold-work silver even in elaborate and sophisticated processes. On the other hand, varying levels of skill can be seen in the manufacture of artefacts even of silver, e.g. coins from the various workshops of the imperial mints.

The heads of the instruments are of varied shape, all potentially useful in a variety of surgical or dental procedures. In the following brief account of each instrument, its Latin name will be used; where this is not forthcoming, the Latinized form of the Greek term will be given.

\section{REF. NO. NAME OF INSTRUMENT, DESCRIPTION, AND POSSIBLE USES}

1559-1568 Olivary nuclei. Diameter $6 \mathrm{mms}$ at maximum. Pharmacy pestles/mixers/stirrers; ${ }^{4}$ when heated, softeners of solid medicaments and cauteries to cure toothache. ${ }^{5}$ The encircling lines could hold fast wool wrappings 6 forming a swab or "bud" to clean or plug a haemorrhage" or to form a dropper for the hot oil frequently used for cauterization or fomentation. ${ }^{8}$

1559 scalpellum/phlebotomum. 9 Double-edged blade shaped like a myrtle-leaf. Length overall $12 \mathrm{cms}$; head $45 \mathrm{mms}$ long $\times 9.5 \mathrm{mms}$ maximum width. Lancet for abscesses ${ }^{10}$ or to cut away the decayed area from a tooth; ${ }^{11}$ gum scarificator and elevator prior to tooth extraction, ${ }^{12}$ scarificator for tooth and gum to relieve toothache and bleeding from the gum (gingivitis). ${ }^{13}$

\footnotetext{
${ }^{3}$ A. Védrènes, Traité de médecine de A. C. Celse, Paris, Libraire de l'Académie de Médecine, 1876, pl. VII, nos. 2-7.

"Celsus VI.6.38 "mix until the substance no longer drops from the end of the probe".

sGalen X.863 "continually apply the very hot tip of the probe"; cf. XIV.355; Laurenz Heister $A$ general system of surgery in three parts, 3rd ed., London, W. Innys, J. Clarke, R. Manby \& H. S. Cox, J. Whiston 1748, vol. I, pl. 20.21 small olivary nucleus cautery for teeth.

- Scrib. Larg. Conp. 230; Celsus VI.8.1B; Paul VI.24.

'Galen X.404; XIV.338.

Celsus VI.9.3+15.4; VII.12.1; Scrib. Larg. Conp. 56; Galen X.863; XIV.355 "fomentations for toothache".

- Celsus VI.18.3B + 4.3; Lucian Adv. Indoct. 29; Galen II.96D; XII.120; XIV.789; Cael. Aur. C.P.2.19; Muscio XVIII.10; XXXIII.92 “flebotomum”; Aet. XVI.101-2.

10 Galen X.1011+415; XIV.781.

"Scrib. Larg. Conp. 53.

12 Galen XIV.785; Paul VI.28.

${ }^{13}$ Galen XIV.433 "scarification of the gums"; cf. Pliny N.H. XXX.3.8+XXXII.7.26.
} 


\section{G. M. Longfield-Jones}

1560 glottokatochon. ${ }^{14}$ Round spatula-probe. Length overall $15 \mathrm{cms}$. Head diameter $16 \mathrm{mms}$. Tongue-depressor. ${ }^{15}$

1561 auriscalpium. ${ }^{16}$ Earscoop. Length overall $14.1 \mathrm{cms}$. Head diameter $10 \mathrm{mms}$. Curette for cleaning small cavities. ${ }^{16}$

1562 spathomele. ${ }^{17}$ Spatula-probe. Length overall $15 \mathrm{cms}$; head shaped like a myrtle-leaf; $17 \mathrm{mms}$ long $\times 9 \mathrm{mms}$ maximum width. Elevator; ${ }^{12}$ scarificator; ${ }^{12,13}$ alveous probe.

1563 spathomele ${ }^{18}$ specilli latitudo. ${ }^{18}$ Spatula-probe. Length overall $15.1 \mathrm{cms}$. Head oar-shaped; length $18 \mathrm{mms}$ long $\times 8 \mathrm{mms}$ maximum width. Used for preparing and applying medicaments. ${ }^{19,20}$

1564-1566 specillum bifurcum..$^{21}$ Three bifurcated probes. Lengths overall $15 \mathrm{cms}$, $15.1 \mathrm{cms}, 15.7 \mathrm{cms}$ respectively. Heads in length $17 \mathrm{mms}, 23 \mathrm{mms}, 25 \mathrm{mms}$ respectively, spatulate but with $\mathrm{V}$-shaped incisions $\mathrm{s}^{22}$ cut into top centre to depths of $4.1 \mathrm{mms}, 4.6 \mathrm{mms}, 4.8 \mathrm{mms}$ respectively. Elevators for molar roots; ${ }^{12}$ possibly directors to hold an instrument steady in the application of medicaments or cauterizing agents. ${ }^{23}$

1567 specillum bifurcum. ${ }^{21}$ Bifurcated probe with two-pronged head in shape not unlike Greek small-letter gamma. ${ }^{24}$ Length overall $13 \mathrm{cms}$; prongs $13 \mathrm{mms}$ long with gap between $6.7 \mathrm{mms}$ maximum width. Dressing/medicament holder. ${ }^{25}$ Possibly holder for a front tooth during the insertion of a fixed prosthesis or wire for securing loose teeth. ${ }^{26}$ In the Pitt Rivers Museum, Oxford, there is an African cautery very like this instrument in shape; Galen recommends the cautery for toothache. ${ }^{5}$

1568 corvus. ${ }^{27}$ "The raven's beak" - a narrow curved blade. Length overall 15.6

\footnotetext{
${ }^{14}$ Heliod. ap. Oribasius 44.14.3; Védrènes, op. cit., note 3 above, pl. II.7.

15 Paul VI.30.

${ }^{16}$ Paul VI.88; Galen XII.122; Scrib. Larg. Conp. 230; Mart. XIV.23; Celsus "oricularium specillum" VII.30.3D; VI.7.5: Heister, op. cit., note 5 above, vol. I, pl. 1.N, small scoop to hold powder to sprinkle on ulcers.

${ }^{17}$ Galen II.724; XII.141; Sor. 2.11.

${ }^{18}$ Galen XII.122; XIV.784; Scrib. Larg. Conp. 227.

19 cf. Pliny. N.H. XXIX.6.37 "spread with a probe".

${ }^{20}$ Scrib. Larg. Conp. 45; Pliny. N.H. XXXIV.11.26 "beat with spatulas"; Aet.XVI.84+50.

${ }^{21}$ Galen XII.155.

${ }_{22}^{2}$ Védrènes, op. cit., note 3 above, pl.VIII.7 head similar but incisions deeper; Heister, op. cit., note 5 above, vol. I, pl. 1, P. similar, described as "spatula, tongue-holder and depressor".

${ }^{23} \mathrm{cf}$. Galen X.863 "a twig of wild majoram dipped in boiling oil is to be applied to the aching tooth"; $\mathrm{cf}$. XIV.355 remedies for teeth and gums Galen X.847-893; XIV.354-358; also Celsus VI passim.

${ }^{24}$ Védrènes, op. cit., note 3 above, pl. VI.7 similar bronze instrument but longer-pronged from Herculaneum; Heister, op. cit., note 5 above, vol. I, pl. 1,0 somewhat similar instrument "spatula, tongueholder \& depressor"; Celsus VII.5.2 "instrument shaped like the Greek letter gamma Y" (weapon probe/remover); Paul VI.6.2 gamma-shaped cauteries.

${ }^{25} \mathrm{cf}$. Galen X.863 medicaments held on "a sharp point" for application to teeth; Celsus VI.9.6 alum in wool inserted into an aching cavity.

${ }^{26}$ Mart. X.56.3 "Cascellius restores an ailing tooth"; Galen XIV.358 loose teeth; false teeth - Hor Serm. 1.8.48; Mart IX.37.3; XII.23; Walter Hoffmann-Axthelm, $A$ history of dentistry, Chicago, Quintessence, 1981 , p. 68, fig. 66, “A Roman gold band denture from Teano S. Italy 300 BC".

${ }^{27}$ Celsus VII.19.7; Paul VI.30; Galen XIV.778 "abscess on the tongue-tonsils and uvula"; XIV.781 lancing of abscesses; Heister, op. cit., note 5 above, vol I, pl. 20 Figs. 17 and 19 similar shape tooth-scalers; Vincenzo Guerini, History of dentistry, Philadelphia and New York, Lea \& Febiger, 1909, p. 52, Fig. 8, similar but shorter blade in Athens Nat. Arch. Mus.
} 


\section{A set of silver dental instruments}

cms; head $24 \mathrm{mms}$ long $\times 4 \mathrm{mms}$ maximum width. Perforator for gumboils, mouth- or ear-abscesses (earache and toothache are often closely associated), lancet for operation on the tonsils ${ }^{12}$ or uvula or for removing tartar or decayed areas of the tooth; ${ }^{11}$ scarificator and stump/root elevator. ${ }^{12,13}$ This type of blade is depicted on several votive and funerary reliefs, e.g.: votive tablet from the Asklepieion, Athens, National Archaeological Museum; doctor's funeral stele from Praeneste, Palazzo Barbarini Museum, Palestrina, no. 32; crude fictile plaque, Ostia Museum no. 5204, funeral relief from Ostia depicting a doctor with an open instrument case - copy in the Wellcome Collection.

Instruments nos. 1559-1562, 1568, and possibly 1567 resemble dental/surgical instruments depicted on a marble tombstone bas-relief in the Lateran Collection. ${ }^{28}$

Two sets of silver/silver-plated instruments closely resembling each other and which, like the New Milton Set, also originated in Asia Minor, have been brought to my attention by Professor Ernst Künzl of the Römisch-Germanisches Zentralmuseum, Mainz. The one comprising twenty-six instruments is in the Medizinhistorisches Museum, Ingolstadt, Bavaria; the other from the Privatbesitz Coldeck, Bremen, contains eighteen instruments, illustrated in Figure 2. Likenesses to the New Milton instruments can be seen in two curved blades, the three bifurcated instruments, and the pointed and oar-shaped spatulas. Professor Künzl has understandable reservations about the usefulness of silver knives for surgical purposes although Lucian $^{29}$ mentions their use by doctors, and Dr Deneffe noted ${ }^{30}$ that most of the instruments from the cache of the Surgeon of Paris were of silver. The blades of instruments nos. 1568, 1559, and 1562 would have sufficed for the dental treatment described in Graeco-Roman texts, i.e. piercing gumboils/abscesses, scarification of diseased gums (prone to bleeding in any case), and the removal of decayed areas of teeth probably already friable. Two types of instrument associated with ancient dental practice are missing from the New Milton Set; a forceps, for removing teeth, ${ }^{31}$ stumps, or roots, ${ }^{32}$ and a rasp or file..$^{33}$ The lack of forceps would not have been critical, as practitioners usually preferred to loosen the tooth so thoroughly beforehand that it could be extracted with the fingers, ${ }^{34}$ and, as has been indicated, for difficult stumps or roots, instruments in the set would have sufficed. The rasp for levelling uneven teeth, removing sharp edges, and areas of decay ${ }^{33}$ would have been missed; Galen considered

\footnotetext{
28 Photograph in the Wellcome Collection WHMM 13705.

29 Lucian Adv. Indoct. 29.

${ }^{30}$ Joseph Maertens, Instruments de chirurgie antique, Ghent, Université de Gand, 1927, p. 7.

${ }^{31}$ Hoffmann-Axthelm, op. cit., note 26 above, p. 71, Fig. 68 bronze dental forceps from a Roman camp at Comitat Aranayos, Hungary (National Museum, Budapest); Wellcome Museum WHMM 13704 photograph of a dental forceps from Roman fort at Saalburg (Guerini, op. cit., note 27 above, p. 114, Fig. 33); Celsus VII.5.2.+4 "forcipe" Varro ap. Non. 99.24 “dentarpaga”; Cael. Aur. T.P. 11.4 (fin.) "dentiducum"; Galen XVII.(1) 911 +Sor. II.63 "odontagra".

${ }^{32}$ Celsus VII.12.1F "rizagram"; Paul VI.28+88 "rhizagra"; Possible example Wellcome Museum No. R1819, Bronze Graeco-Roman, $7.8 \mathrm{cms}$.

${ }^{33}$ Aet. VIII.82 "rhinarion"; Celsus VI.6.27 "asperatum specillum".

${ }^{34}$ Celsus VII.4.4B+12.1; VI.9.5+6; Galen XIV.431-2.
} 


\section{G. M. Longfield-Jones}

it so important that he had a special small file, ${ }^{33}$ apparently of his own devising. Unlike the forceps, the rasp would have been of a size to have been housed with the set in a cylindrical case, box, or bag. It must be presumed lost with the instrument-case, but, given its inclusion, the set would have met the chief needs of ancient dental practice, namely, to alleviate pain, treat gum and mouth infections, render the tooth serviceable or extract it as a last resort, strengthen loose teeth, or insert substitutes.

\section{DATING OF THE INSTRUMENTS}

Instruments of the four basic types which make up this dental set, namely, lancet (straight and curved blade), earscoop (curette), bifurcated probe, spatula-probe (heads round, oar- or leaf-shaped, or modified for specific use), may be recognized in finds from Pompeii, Herculaneum, and other settlements throughout the Roman world; they are also mentioned in medical texts from the first to the seventh centuries AD. In order to place the instruments of the dental set more precisely, if possible, within this time range, we compared their metal composition with that of positively identified and dated silver artefacts whose analyses had been recorded. Non-destructive tests were carried out ${ }^{36}$ upon two of the instruments, nos. 1561 and 1564 . The resultant figures ${ }^{37}$ were considered alongside those for a second-century AD coin ${ }^{38}$ of the Empress Vibia Sabina, minted at Rome, and were found to be comparable except that the lead content in the instruments $(0.01 \%)$ was somewhat low. ${ }^{39}$ However, comparison with analyses $^{40}$ of two items of Late Roman plate and two of Sassanian plate from the third

3s Galen XII.871+872 "rhinion".

${ }^{36} \mathrm{X}$-ray fluorescence at the Laboratory for Archaeology and the History of Art, Oxford University, by Dr A. M. Pollard whose helpful notes on these analyses and on Late Roman silver I acknowledge; the responsibility for their interpretation and for any erroneous conclusions drawn, is entirely mine.

37

$\begin{array}{crrr}\begin{array}{c}\text { Reference } \\ 1561\end{array} & \text { Wt } \% & \mathrm{Ag} & \mathrm{Cu} \\ 1564 & & 90.3 & 9.5 \\ { }_{38} & \text { Item } & 90.9 & 9.0 \\ & 9 & \text { Code no. } & \text { Coin Ref. } \\ & 9 & \text { B.M.133 } & \text { RIC 398 } \\ & & \text { Sabina } & \end{array}$

silver gold copper

$90.31 \quad 0.029 \quad 9.20$

\section{Instrument}

$\begin{array}{ccccc}\mathrm{Zn} & \mathrm{Au} & \mathrm{Pb} & \mathrm{Sn} & \mathrm{Ni} \\ 0.10 & <0.05 & <0.01 & <0.5 & <0.01 \\ 0.05 & <0.05 & <0.01 & <0.5 & <0.01\end{array}$

$\mathrm{Ni}$

$<0.01$

Edward T. Hall and David M. Metcalfe, 'Methods of chemical and metallurgical investigation of ancient coinage', Royal Numismatic Society Special Publications, 1972, 8: 42-43.

${ }^{39} \mathrm{M}$. J. Hughes and J. A. Hall, 'X-Ray fluorescent analysis of late Roman and Sassanian silverplate', J. archaeol. Sci., 1979, 6: 332: "Roman smiths could produce very pure silver if necessary"; David Sellwood, Roman crafts, London, Duckworth, 1976, p. 64 (on Roman silver): "silver too after being cupelled from lead (leaving as little as 0.01 per cent behind) ...". These are not unacceptable statements judging from an analysis of a silver vase found in Egypt which has a nil lead content. See Hughes and Hall, op. cit., note 39 above, p. 322 quoting J. and P. Meyers, Mishara, 1974, p. 37: "Object Vase, Provenance Egypt; Silver $98.2 \%$, Copper $1.7 \%$, Gold $0.05 \%$, Lead Nil, Iron Nil. The date of the vase not stated; the figures here given are intended to be taken as evidence of the skill of ancient silversmiths in general, so that the figure of $0.01 \%$ lead in the dental instruments by no means casts doubt upon their antiquity."

${ }^{40}$ Hughes and Hall, op. cit., note 39 above, p. 326: Water Newton Silver Hoard, Cat. Ref. PRB 1975 102-2, 8: silver $97.9 \%$, copper $1.82 \%$, gold $0.2 \%$, lead $0.04 \%$, zinc $1.0 \%$, p. 329 Cat. Ref. Augst 62.2 (Seacity dish; central panel): silver $98.6 \%$, copper $0.96 \%$, gold $0.39 \%$, lead $0.05 \%$, zinc $000 \%$; p. 328 Cat. Ref. 13304 


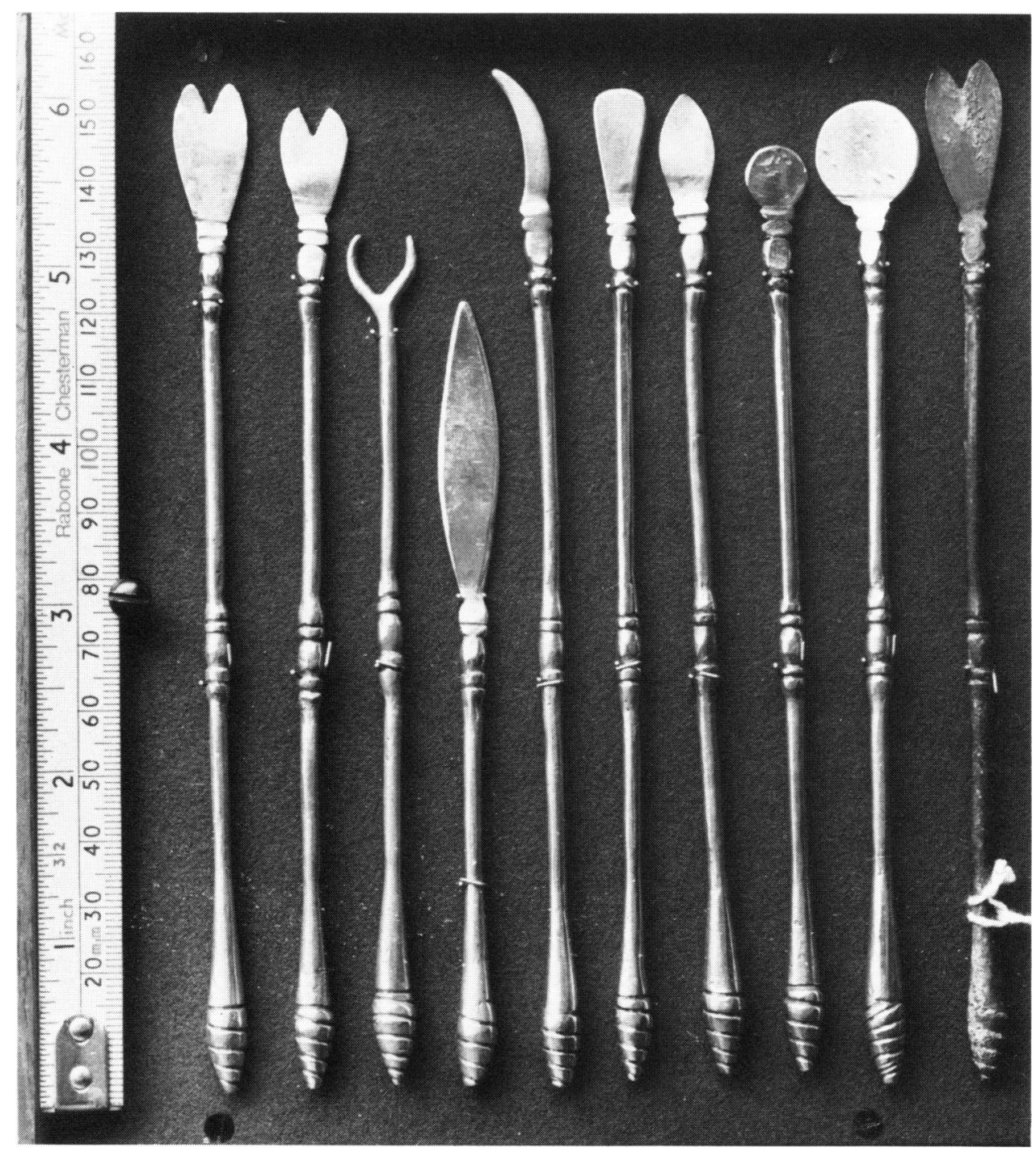

Figure 1. Set of ten Roman silver instruments from the New Milton Collection, identically decorated, sold as dentists' instruments. Provenance unknown. Numbered left to right: 1565, 1564, 1567, 1559, 1568, $1563,1562,1561,1560,1566$. 


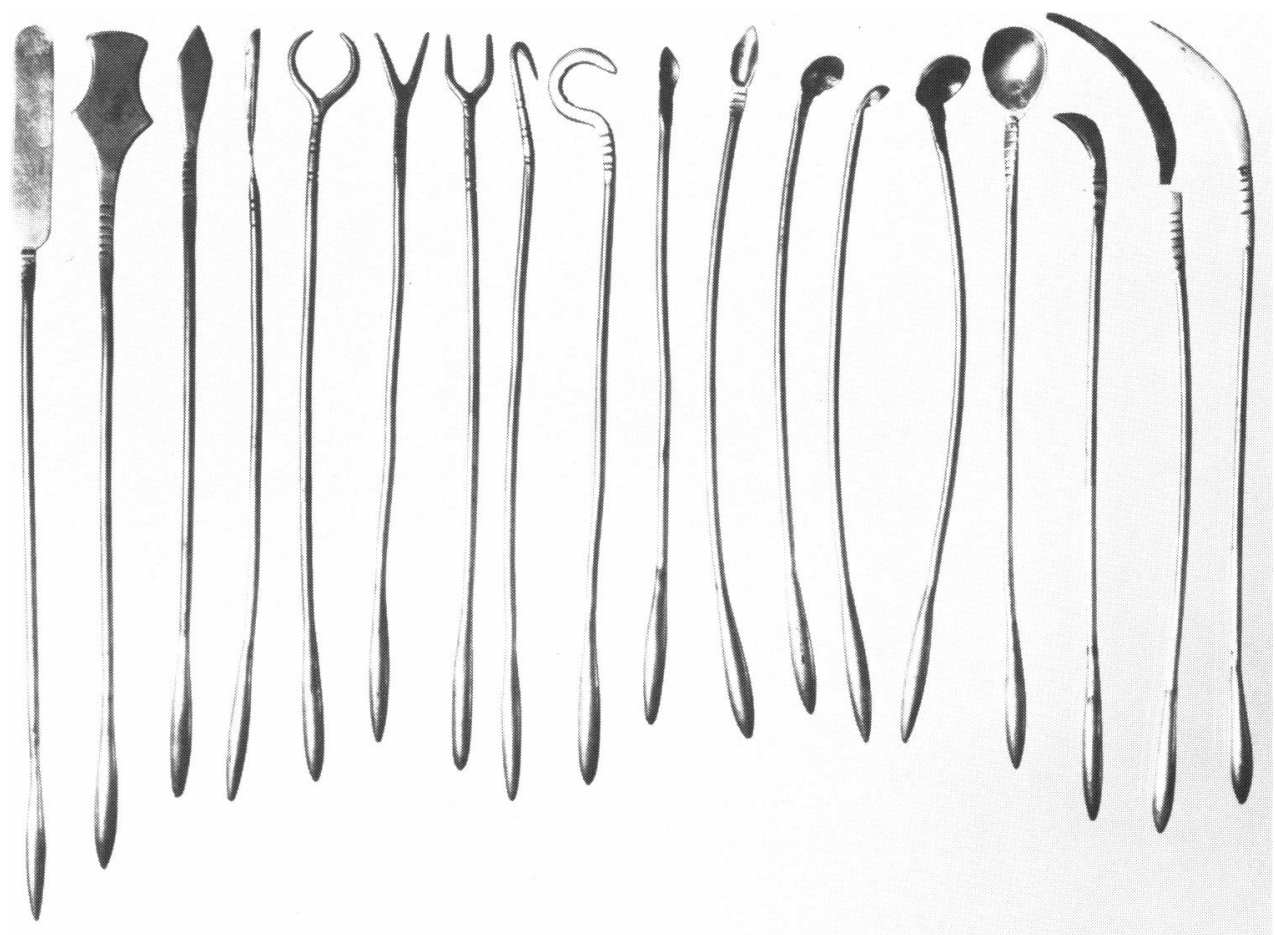

Figure 2. Set of instruments from a private collection in Bremen, Germany. 
to the seventh centuries $A D$, gave figures for lead $(0.04 \% ; 0.05 \% ; 0.07 \% ; 0.05 \%$ respectively), much more like the lead content of the instruments. To judge from these figures, admittedly scanty, the dating of the instruments would seem to be late Roman, and from their place of origin, Eastern Imperial period. Stylistically this is difficult to confirm because positively identified Byzantine medical instruments are rare, but if we consider the decline in elegance of the official coinage from the sixth century AD onwards, the rather inferior decoration of the dental set may possibly be taken as confirmatory evidence. It would have been useful to have compared in style and metal composition the instruments of the inheritors of the Graeco-Roman medical tradition, the Arabian doctors of the ninth and tenth centuries AD, but examples of this date are difficult to find.

Illustrations in an eleventh-century manuscript of Albucasis ${ }^{41}$ show instruments with typically Arabian finials, but the working heads of some resemble those of the dental instruments: curved blade and round spatula (cauteries), small round spatula (small lenticular knife), pronged bifurcated probe and pointed spatula (dental scrapers), ${ }^{42}$ curved blades (elevators). ${ }^{42}$ Later Islamic instruments from the seventeenth to the nineteenth centuries, although extremely beautiful in design and appearance, give only a few indications of classical derivation. In the elegant set of ten bronze instruments at Athens in the Benaki Museum (no. 13285) the simple silver inlay pattern found only on the handles of instruments of the Gallo-Roman oculists of the third century, ${ }^{43}$ has become highly ornamental gold, covering the whole instrument completely in most cases and extending even to the cutting blades; one bellied blade in combination with an olivary nucleus probe is somewhat reminiscent of the ancient prototype. The ornate late eighteenth-century set in the Wellcome Museum ${ }^{44}$ contains damascened blades but the horn handles of four of the knives, a probe, and forceps are very dissimilar to the Greek and Roman surgical instruments.

The dental set is in no way comparable to these instruments. A set of eleventh- to twelfth-century Turkish dental instruments from the Nidai Ergun private collection ${ }^{45}$ contains instruments of the earscoop type and one head is like the New Milton curette. Illustrations of instruments from the fifteenth-century Ottoman Empire doctors, Seref Ed-Din ${ }^{46}$ and Abū'l Qasīm, ${ }^{47}$ show the small-pronged bifurcated probe, the pointed leaf-shaped spatula/knife, and extremely long curved blades; ten from

(Dish body. King and three lions): silver $99.6 \%$, copper $0.18 \%$, gold $0.05 \%$, lead $0.07 \%$, zinc $0.02 \%$; Cat. Ref. 123063 (Plaque. Two dogs attack): silver $97.2 \%$, copper $2.4 \%$, gold $0.28 \%$, lead $0.05 \%$, zinc $1.0 \%$; p. 334 extra effort in cupellation by Sassanian smiths regularly produced very pure silver.

${ }^{41}$ Reproduced in Mario Tabanelli, Albucasi, Florence, Olschki, 1961, Ill. VII p. 103, XXXII Lib III, Cap II, V, p. 101 \& VIII p. 116+XXVI Lib. II Cap XXXXVIII, XIX p. 137 del Codice Latino della Biblioteca Universitaria di Montpellier.

22 Guerini, op. cit., note 27 above, p. 129, Fig. 35, and p. 134, Fig. 44.

${ }^{43}$ Finds of Severus - St Germain-en-Laye Museum and of Sollemnis - Le Puy-en-Velay Museum, described by John St Milne, Surgical instruments in Greek and Roman times, Oxford, Clarendon Press, 1907, pp. 174-175.

44 Wellcome Museum A642946/1-11.

is Arslan Terzioglu and Linda Marion Knebs, The history of old Turkish dentistry, Munich. Demeter Verlag, 1980, p. 19, Fig. 2c.

${ }^{46}$ Ibid., p. 18, Fig. 2a, from the Bibliotheque Nationale, Paris, MSS. Suppl. turc. Nr. 693, folio 73, of MSS. by Seref-Ed-Din Sabuncuóglu.

${ }^{47}$ Ibid., p. 18, Fig. 2b, Trans. of Abū'l Qāsım's At-Tasrif Kitābi Zāhrāwî (Manīsa Library, Turkey, Nr. 1844, folio 26). 


\section{G. M. Longfield-Jones}

Abū'l Qasīm's set have nucleated finials. ${ }^{48}$ Description of dental treatment echoes Graeco-Roman medical texts: cauterization for gingivitis, ${ }^{49}$ filing of supernumerary teeth ${ }^{30}$ lancing of swellings under the tongue, ${ }^{51}$ fixation of loose teeth with wire, ${ }^{32}$ and scraping/scaling teeth with a curved-bellied blade. ${ }^{53}$ Among fifteenth- to sixteenthcentury bronze dental instruments from the Nidai Ergun private collection ${ }^{54}$ there are fourteen that appear identical with Pompeian artefacts in design and decoration (rings and baluster pattern); of these, an oar-shaped spatula-probe with olivary nucleus and a pronged bifurcated probe (?with damaged head) can be compared with the New Milton set, also possibly a "make-do" scaler/cautery fashioned by bending into a curve the pierced shaft of a large domed-headed pin.ss

Other instruments reminiscent of the Graeco-Roman type in style of decoration and design may be seen in two sets (one ophthalmic, ${ }^{56}$ the other surgical ${ }^{57}$ dating from the seventeenth or eighteenth century, in the Germanisches National-Museum at Nuremberg. Four of these instruments have working heads not unlike those in the dental set, i.e. a curved blade, two small curettes (earscoops), and a pointed spatula; there is also a bifurcated probe but its prongs are longer. The surgical set is described as of "iron with brass handles", 37 recalling Roman scalpels with steel/iron blades in bronze handles.

The classical design of instrument was in use in later centuries. Indeed, a dating on stylistic grounds later than the seventh century AD cannot be excluded. To sum up, the dental instruments of the New Milton Collection are Graeco-Roman in type and of a silver "more free of trace elements than much used in Roman imperial coinage";s8 they would have been costly enough in appearance to have impressed a prospective patient and, because of the addition of $9.20 \%$ bronze/copper, ${ }^{59}$ would have proved durable enough for use by a Graeco-Roman doctor or dentist. ${ }^{60}$

\section{ACKNOWLEDGEMENTS}

I am grateful to Dr Vivian Nutton of the Wellcome Institute for help and advice in this project, also to Mr Richard Hattat of New Milton and Professor Ernst Künzl of Mainz Römisch Germanisches Zentralmuseum for providing Figures 1 and 2 respectively.

4 Ibid., p. 21, Fig. 2 e.

49 Ibid., p. 26, Fig. 5a (Seref-Ed-Din).

so Ibid., p. 34, chap. 35.

51 Ibid., p. 33, chap. 32.

32 Ibid., p. 24, Fig. 4 (Abu'l QasTm).

s3 Ibid., p. 25, Fig. 5a (Paris MSS. Suppl. turc. Nr. 693, folio 72a).

s4 Ibid., p. 68, Fig. 16a, and p. 69, Fig. 16b.

ss Cloak-pin, "toggle" type found in Palestine and N. Africa and probably brought by Jewish doctors popular at Ottoman Court.

${ }^{56}$ Geerto Snyder, Instrumentum medici, Ingelheim-am-Rhein, C. H. Boehringer Sohn, 1972, p. 103, Fig. 73; and Ernst Königer, Aus des Geschichte der Seilkunst von Aerzten, Badern und Chirurgen, Munich, Prestel Verlag, 1958, Fig. 23.

s7 Ibid., Fig. 36. I am again indebted to Prof. Ernst Künzl for bringing these sets to my attention.

s8 I express my thanks to Prof. John Healy of Royal Holloway College, University of London, for this assessment of the metal and for bringing to my notice analyses of Roman coins.

59 M. J. Hughes and J. A. Metcalf, 'X-Ray fluorescent analysis of Late Roman and Sassanian silver plate', J. archaeol. Sci., 1979, 6: 322-323.

${ }^{60}$ Dentistry was an integral part of general medical practice, although there were professional dentists in antiquity; cf. Martial X. 56.3, and an illustration of representation forceps and extracted tooth, upon a tombstone, from Bulletino di archaeologia cristiana, 1894, 5-photograph Wellcome Collection N. 13706. 